American Journal of Pharmaceutical Education 2021; 85 (2) Article 8232.

\title{
BRIEF
}

\section{Pharmacy Students' Perception of an Elective Course on Evidence-based Learning Strategies}

\author{
Ike de la Peña, PhD, Kathryn Knecht, PhD, Paul Gavaza, PhD \\ Loma Linda University, School of Pharmacy, Loma Linda, California \\ Submitted June 12, 2020; accepted October 30, 2020; published February 2021.
}

Objective. To examine pharmacy students' perceptions of an elective course on evidence-based learning strategies.

Methods. Pre- and post-course survey questionnaires were administered to students who enrolled in an elective course, to determine the learning strategies they used prior to course attendance, track their use of evidence-based learning strategies and observance of healthy lifestyle habits, and assess their perception of the course. A written assignment was given that required students to reflect on the learning outcomes that resulted from their application of evidence-based learning strategies. Mean scores on the pre- and post-course survey were analyzed using a general linear model repeated measures test.

Results. The 59 students in this study predominantly used less-effective strategies (eg, re-reading and re-writing of notes) prior to taking the course. They reported increased use of evidence-based learning strategies, particularly retrieval practice and elaboration, and practice of healthy lifestyle habits (ie, enough sleep, exercise, good nutrition) after course completion. Students believed that using the above learning strategies improved their learning and memory and performance on graded assessments, among other benefits. Students had a positive perception of the course.

Conclusion. The elective course was associated with increased use of effective learning strategies, adoption of healthy lifestyle practices that aid learning, and increased appreciation for evidence-based learning strategies by the students. Future studies are needed to examine actual learning outcomes and barriers to implementation of evidence-based learning techniques.

Keywords: evidence-based learning strategies, retrieval practice, elaboration, elective course

\section{INTRODUCTION}

Decades of research have identified cognitive strategies and lifestyle habits that enhance learning and memory. ${ }^{1-5}$ For instance, various benefits have been shown from retrieval practice or testing oneself, which researchers have advocated as a means of enhancing and not just assessing knowledge in educational policy. $2,3,6$ Another evidence-based learning strategy is elaboration, which involves connecting new information to preexisting knowledge or learning by asking "how" or "why" questions. $^{2}$ Adopting healthy habits such as getting enough sleep, physical exercise, and proper nutrition has also been found to improve cognition, learning, and storage of memories. ${ }^{4,7-9}$

Despite these findings, many students, including pharmacy students, use less-effective study techniques,

Corresponding Author: Ike C. de la Peña, Loma Linda University, School of Pharmacy, Department of Pharmaceutical and Administrative Sciences, 11175 Campus St., Ste. 21008, Loma Linda, CA 92350. Tel: 909-651-5995. Email: idelapena@1lu.edu eg, rereading and highlighting notes. ${ }^{6,10-17}$ Moreover, recent surveys reported that students experienced poor sleep quality, high levels of perceived stress, and inconsistent feelings of overall well-being, all of which could affect their overall mental health and academic performance. ${ }^{18-23}$ Because pharmacy students must learn an enormous amount of information at a rapid pace, using evidence-based strategies and practicing healthy lifestyle habits to enhance encoding, storing, and recalling learned information is critically important. Furthermore, the lifelong learning needed for successful independent practice requires metacognitive skills, including the understanding and use of effective learning strategies. ${ }^{10,11,24-26}$ Indeed, the Center for the Advancement of Pharmacy Education includes metacognition as part of self-awareness, one of the required educational subdomains in pharmacy education. ${ }^{27}$ Furthermore, given the link between healthy habits and learning, the American Association of Colleges of Pharmacy (AACP) encouraged schools of pharmacy to contribute to and promote a culture of wellness and resilience among students. ${ }^{28}$ 


\section{American Journal of Pharmaceutical Education 2021; 85 (2) Article 8232.}

In fall 2019, we introduced the Learning and Memory elective course to Doctor of Pharmacy (PharmD) students at Loma Linda University (LLU). This 20-hour course featured evidence-based learning strategies, including healthy habits that promote learning. We conducted a single-center, retrospective pilot study to determine whether the didactic teaching of evidencebased learning strategies and healthy lifestyle habits promoted the use of these techniques and practices among pharmacy students, evaluate whether students had developed an awareness of the benefits of evidence-based learning techniques after attending the course, and assess students' perception of the elective course.

\section{METHODS}

This study included first through third professional (P1-P3) year PharmD students who took the Learning and Memory elective course offered during fall 2019. There were no eligibility criteria to sign up for the course. A paper-based survey was administered to students on the first day of the class to identify the study strategy(ies) that they thought most effectively worked for them, and to assess their awareness and use of evidence-based learning strategies (eg, retrieval practice, spacing, interleaving, elaboration, chunking, dual coding, teaching others). The survey also asked how often the students practiced the healthy lifestyle habits (eg, enough sleep, exercise, good nutrition) that promote learning. Participant demographics (gender, age, and year level) were also collected. The survey questions were developed by the investigators based on a literature review of evidence-based learning strategies, including lifestyle habits that promote learning. The questionnaire was piloted to a small group of pharmacy students who were not enrolled in the course, and survey items were revised for clarity and reliability based on respondents' feedback. With the exception of question 1 , a four-point Likert scale ( $4=$ always, $3=$ occasionally, $2=$ rarely, and $1=$ never) was used for all survey responses.

As course requirements, students applied the learning strategies and submitted a written assignment describing the frequency of use and their perceptions of the effectiveness, benefits, and advantages of the different learning strategies. We further explored the learning outcomes associated with use of retrieval practice and elaboration, which were frequently used by the students as per the results of the post-course survey. At the end of the course, students completed two anonymous surveys. The first one included all the pre-course survey questions, while the second one examined students' perceptions of the elective course. A four-point Likert scale (no neutral response option) was used to obtain specific responses to the survey questions. The study was determined to be exempt by LLU Health Institutional Review Board.

The responses to open-ended questions and the written assignment were analyzed using an inductive, grounded theory-based approach. ${ }^{29}$ The quantitative data were inputted into Excel, and uploaded to IBM SPSS, version 25 (SPSS Inc.) for statistical analysis. Descriptive statistics were computed for all study variables where appropriate. A general linear model repeated measures procedure was used to compare the mean scores between the pre- and post-course surveys. Chi-square tests were used to determine the relationships between categorical variables. An a priori alpha level of less than or equal to .05 was considered significant.

\section{RESULTS}

Fifty-nine (98\%) of the 60 students who took the course completed the survey instruments and submitted the written assignment. Of these students, $34 \%(n=20)$ were $\mathrm{P} 1$ students, $61 \%(\mathrm{n}=36)$ were $\mathrm{P} 2$ students, and $5 \%$ $(\mathrm{n}=3)$ were P3 students. There were more female $(76 \%$, $\mathrm{n}=45)$ than male $(24 \%, \mathrm{n}=14)$ participants in this study. Their ages ranged from 22 to 41 years, with a mean age of $27.5(\mathrm{SD}=4.1)$ years.

The pre-course survey revealed that the majority of students used less-effective techniques such as rereading/ re-watching lectures and rewriting notes (Table 1). Use of effective learning strategies (eg, practice tests, drawing/ diagrams) was less common. The post-course survey revealed that retrieval practice was rated as the most effective learning strategy $(41 \%, n=24)$, followed by spacing $(27 \%, n=16)$, dual coding $(10 \%, n=6)$, elaboration $(6.8 \%, n=4)$, method of loci $(5.1 \%, n=3)$, interleaving $(5.1 \%, n=3)$, and others. There was a significant increase in students' use of retrieval practice (statement 1 , $p<.05$ ) and elaboration (statement $4, p<.05$ ) (Table 2), and practice of healthy habits that enhance learning (statement 9, $p<.01$ ) (Table 2).

Analysis of the written assignments revealed that students used retrieval practice more than once a week to more than once a day (data not shown). Students "created [their] own practice questions and answered them" $(n=14)$, used "flashcards" $(n=10)$, "recalled information without looking at notes" $(\mathrm{n}=9)$, "answered practice tests or quizzes" $(n=7)$, etc. Students perceived that retrieval practice was an effective tool to study for their courses $(\mathrm{n}=18)$, improved their confidence in answering questions $(n=3)$, and facilitated easy recall $(n=10)$ and longterm retention of information $(n=7)$. They also believed that use of retrieval practice improved their performance in graded assessments $(n=31)$. Students wrote that the advantages of using retrieval practice included 
American Journal of Pharmaceutical Education 2021; 85 (2) Article 8232.

Table 1. Strategies Used by Pharmacy Students Prior to Taking an Elective Course on Evidence-based Learning Strategies

\begin{tabular}{|c|c|c|}
\hline $\begin{array}{l}\text { Most Effective Learning Strategy for } \\
\text { Students }^{\mathrm{a}}\end{array}$ & $\begin{array}{l}\text { Students Listing the Strategy, \% } \\
(\mathrm{N}=60)\end{array}$ & $\begin{array}{c}\text { Corresponding Course } \\
\text { Learning Strategy } \\
\end{array}$ \\
\hline Rereading/rewatching & 51.0 & - \\
\hline Rewrite notes & 33.0 & - \\
\hline Drawing/diagram/charts ${ }^{\mathrm{b}}$ & 19.0 & Dual Coding \\
\hline Learning major concepts first ${ }^{b}$ & 8.4 & Chunking \\
\hline Study with others & 6.7 & Group Study \\
\hline Practice tests & 5.0 & Retrieval Practice \\
\hline Memorize & 3.3 & - \\
\hline Flashcards & 3.3 & Retrieval Practice \\
\hline Relating new material to old material & 3.3 & Elaboration \\
\hline Mnemonics & 1.7 & Elaboration \\
\hline Teach others & 1.7 & Teach Others \\
\hline Highlight & 1.7 & - \\
\hline Studying one subject at a time $\mathrm{b}$ & 1.7 & - \\
\hline Completing practice problems & 1.0 & Retrieval Practice \\
\hline
\end{tabular}

a Students' responses to question 1 of the pre-course survey: "What study strategies most effectively work for you?" Responses were classified according to categories described in previous studies. ${ }^{6,33}$ They were also mapped to the corresponding learning strategies introduced in the course. Some students mentioned multiple answers, therefore, percentages of listing do not add to $100 \%$

${ }^{\mathrm{b}}$ Responses that did not fit into any of the previously described categories

improvement of learning and memory $(\mathrm{n}=21)$, reduction of test anxiety $(\mathrm{n}=10)$, the convenience associated with the use of this strategy once questions had been created $(n=7)$, etc. Nine students wrote that retrieval practice was more effective than other strategies. Nevertheless, 34 students reported that use of retrieval practice required time and effort, presumably because of the time needed to generate questions. Some students reported uncertainty about the quality of the questions they made $(n=10)$ or the inadequacy of the retrieval practice $(n=10)$ to foster deeper learning.

The frequency of students' use of elaboration ranged from more than once a week to more than once a day. Application of this strategy included "using own words" $(\mathrm{n}=20)$, "asking how and why questions" $(\mathrm{n}=20)$, "connecting to previously learned information" $(n=15)$, "explaining to others" $(\mathrm{n}=4)$ and "relating concepts to self" $(n=1)$. Students wrote that elaboration made studying more effective $(n=19)$, resulted in long-term retention of information $(n=6)$, and helped in developing organizational $(n=5)$ and explanation $(n=9)$ skills. The strategy's advantages included improving learning and memory $(n=34)$, making connections $(n=14)$, promoting active processing of information $(n=10)$, etc. Nevertheless, some students commented that incorrect use of this strategy $(n=15)$, such as overelaborating, overthinking, or thinking of the wrong information from the very beginning, is a drawback to this strategy. Elaboration also required time and effort $(n=14)$. Some students also faced some challenges in applying this strategy as it required some prerequisite skills $(\mathrm{n}=11)$, such as "thorough knowledge of the material being learned" or "mastering concepts before making elaborations."

Many students agreed (46\%) or strongly agreed $(12 \%)$ that they were not aware of evidence-based learning strategies prior to taking the course (Table 3). Most of the students (98\%) reported that they had applied the learning strategies introduced in the class and agreed that the knowledge and skills they developed in the course helped them effectively study for their other courses. All students believed that the principles learned in the course could help them prepare for clinical practice. Most students $(98 \%)$ agreed that they would suggest this course to their peers, and $73 \%$ of students strongly recommended the inclusion of the Learning and Memory elective course in the required pharmacy curriculum. Finally, $97 \%$ of the students believed that faculty should teach not only content but also study techniques in their courses.

\section{DISCUSSION}

Pharmacy students reported increased use of effective learning strategies, particularly retrieval practice and elaboration; more frequent adoption of healthy lifestyle habits that potentiate learning; and appreciation for evidence-based learning strategies as a result of completing an elective course. Therefore, the course fostered students' use of optimal learning practices, which could facilitate student academic success and provide an indispensable foundation for lifelong learning habits that could contribute to successful clinical practice. ,11,26 $^{1,2}$ 
American Journal of Pharmaceutical Education 2021; 85 (2) Article 8232.

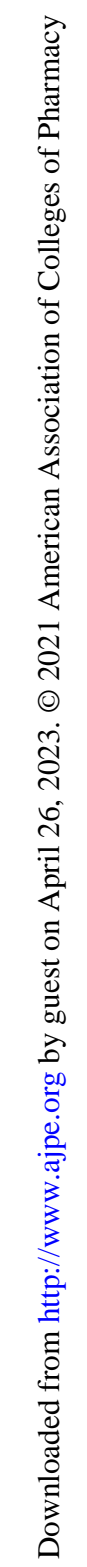

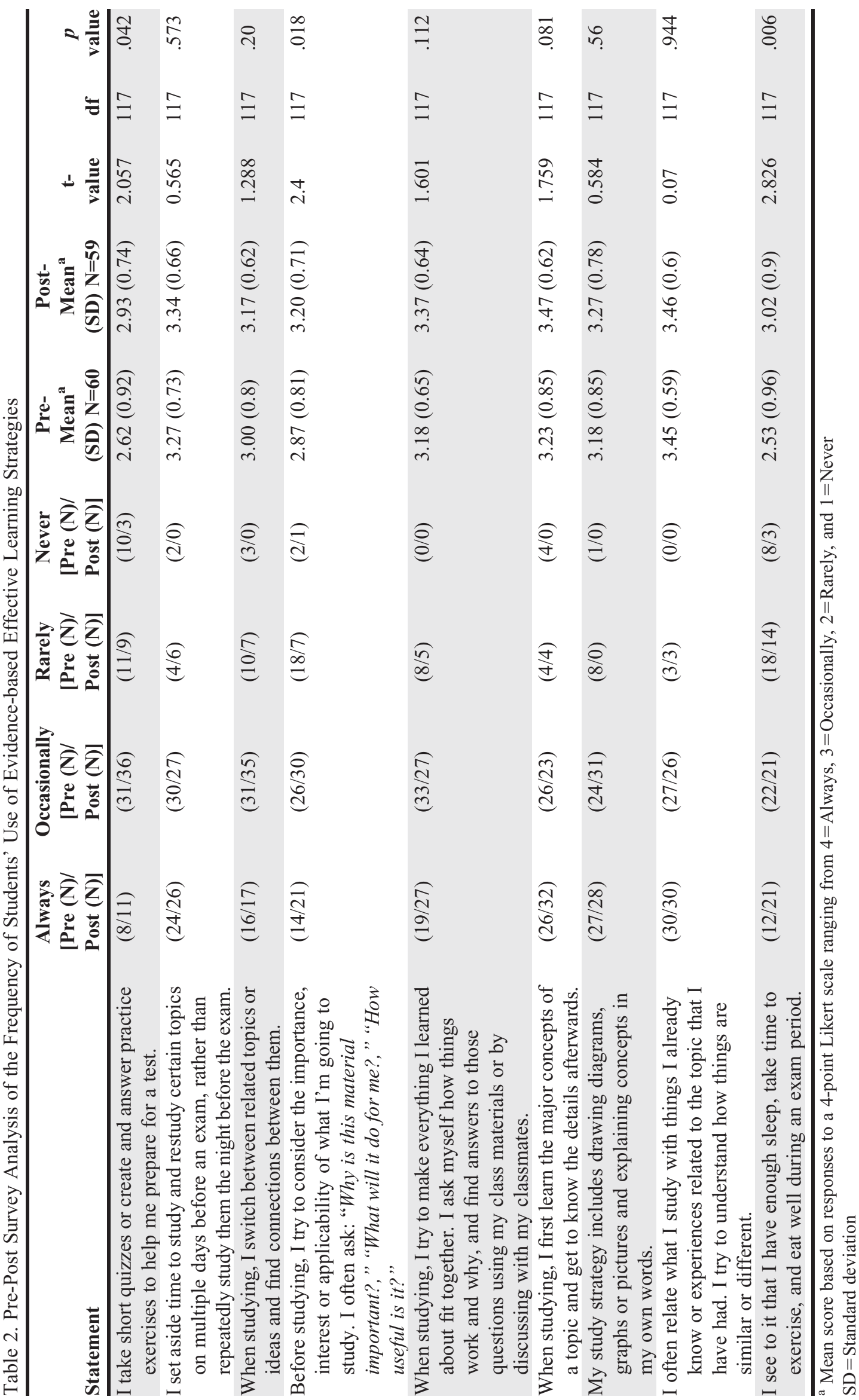


American Journal of Pharmaceutical Education 2021; 85 (2) Article 8232.

Table 3. Pharmacy Students' Perception of the Learning and Memory Elective Course

\begin{tabular}{|c|c|c|c|c|}
\hline Statement & $\begin{array}{c}\text { Strongly } \\
\text { Disagree, } \\
\%(\mathrm{~N})\end{array}$ & $\begin{array}{l}\text { Disagree, } \\
\%(\mathbf{N})\end{array}$ & $\begin{array}{l}\text { Agree, } \\
\%(N)\end{array}$ & $\begin{array}{c}\text { Strongly } \\
\text { Agree, } \\
\%(\mathrm{~N})\end{array}$ \\
\hline $\begin{array}{l}\text { I was NOT aware of evidence-based effective learning strategies (eg, retrieval } \\
\text { practice, spaced practice, interleaving) prior to taking this course. }\end{array}$ & $15(9)$ & $27(16)$ & $46(27)$ & $12(7)$ \\
\hline I have applied the learning strategies taught in this course. & $0(0)$ & $2(1)$ & $56(33)$ & $42(25)$ \\
\hline $\begin{array}{l}\text { The knowledge and skills I developed through this course helped me to } \\
\text { effectively study for my other courses. }\end{array}$ & $0(0)$ & $2(1)$ & $56(33)$ & $42(25)$ \\
\hline $\begin{array}{l}\text { The knowledge and skills I developed through this course will prepare me } \\
\text { for my clinical practice. }\end{array}$ & $0(0)$ & $0(0)$ & $47(28)$ & $53(31)$ \\
\hline I would suggest this course to my peers. & $0(0)$ & $2(1)$ & $14(8)$ & $85(50)$ \\
\hline $\begin{array}{l}\text { I would suggest the inclusion of Learning and Memory Elective Course in } \\
\text { School of Pharmacy Curriculum. }\end{array}$ & $0(0)$ & $5(3)$ & $22(13)$ & $73(43)$ \\
\hline $\begin{array}{l}\text { I think teachers should teach not only content but also study techniques in } \\
\text { their classes. }\end{array}$ & $0(0)$ & $3(2)$ & $26(15)$ & $71(42)$ \\
\hline
\end{tabular}

Students believed that use of retrieval practice and elaboration enhanced their learning and memory and helped them perform well in graded assessments, as well as having other benefits. This finding adds to the literature on the perceived and tangible learning outcomes associated with use of these evidence-based learning strategies. ${ }^{1-3,10,30-35}$ Specifically, in pharmacy education, providing access to online quizzes or test-enhanced learning modules paired with corrective feedback improved retention of course materials and student performance. ${ }^{31,36}$ The use of elaboration also improved non-pharmacy students' acquisition of knowledge. $35,37,38$ Notably, many students remarked on the effectiveness of retrieval practice when used as a tool to study for their courses, in retrieving information and remembering them long term. These are effective applications of this strategy $^{3}$ as opposed to using it to evaluate the status of one's learning. ${ }^{3,13,16}$ Nevertheless, students commented that retrieval practice and elaboration required time and effort, which may affect adherence to these learning strategies. ${ }^{30,39}$ For educators, informing students about the lasting learning benefits of using strategies that create desirable difficulties (eg, retrieval practice and elaboration), and incorporating them in instruction (eg, providing practice questions, prompting students to generate selfexplanations of a problem or solution), could mitigate the perceived drawbacks and encourage sustained use of evidence-based learning methods. ${ }^{26,30,39}$

Students also reported that as a result of this course they more frequently practiced healthy habits that enhance learning. This is an encouraging finding given the impact of rigorous health profession programs, such as the PharmD program, on student well-being and academic achievement, and the recent suggestion of the AACP for the implementation of wellness efforts in pharmacy schools. ${ }^{19,22,23,28,40,41}$ Future studies should examine the direct impact of the different lifestyle habits taught in this course on student well-being and academic performance.

Overall, students' perception of the course was positive. Importantly, most students believed that the elective course helped them study for their courses and to prepare them for their clinical practice. Therefore, training in evidence-based learning strategies increased students' appreciation of the value of these strategies to equip them to learn more effectively in various educational situations and to meet the lifelong learning demands of their prospective profession. Finally, nearly all of the students believed that teachers should not only teach content but also learning strategies in their courses. This reinforces the previous recommendation for pharmacy educators to teach evidence-based learning strategies in addition to course content. ${ }^{6,11}$

The small sample size, which limits generalizability of the findings, and use of crude survey instruments to assess learning outcomes are some of the limitations to this study. Social desirability response bias, prior interest in evidence-based learning strategies, and use of a fourpoint Likert scale may have also influenced students' responses on surveys and outcomes.

\section{CONCLUSION}

This elective course increased awareness and promoted use of evidence-based learning strategies among pharmacy students. It also encouraged practice of healthy lifestyle habits that complement learning. Follow-up studies are needed to determine links between use of evidencebased learning strategies, perceived outcomes, and actual tangible impacts on student's academic performance. 


\section{American Journal of Pharmaceutical Education 2021; 85 (2) Article 8232.}

\section{REFERENCES}

1. Dunlosky J, Rawson KA, Marsh EJ, Nathan MJ, Willingham DT. Improving students' learning with effective learning techniques: promising directions from cognitive and educational psychology. Psychol Sci Public Interest. 2013;14(1):4-58.

2. Weinstein Y, Madan CR, Sumeracki MA. Teaching the science of learning. Cogn Res Princ Implic. 2018;3(1):2.

3. Hartwig MK, Dunlosky J. Study strategies of college students: are self-testing and scheduling related to achievement? Psychon Bull Rev. 2012;19(1):126-134.

4. Maquet P. The role of sleep in learning and memory. Science. 2001;294(5544):1048-1052.

5. Cooper C, Moon HY, van Praag H. On the run for hippocampal plasticity. Cold Spring Harb Perspect Med. 2018;8(4).

6. Persky AM, Hudson SL. A snapshot of student study strategies across a professional pharmacy curriculum: are students using evidence-based practice? Curr Pharm Teach Learn. 2016;8(2): 141-147.

7. Krause AJ, Simon EB, Mander BA, et al. The sleep-deprived human brain. Nat. Rev. Neurosci. 2017;18(7):404-418.

8. Cassilhas RC, Tufik S, de Mello MT. Physical exercise, neuroplasticity, spatial learning and memory. Cell Mol Life Sci. 2016; 73(5):975-983.

9. Cooper RE, Tye C, Kuntsi J, Vassos E, Asherson P. Omega-3 polyunsaturated fatty acid supplementation and cognition: A systematic review and meta-analysis. J Psychopharmacol. 2015; 29(7):753-763.

10. Hagemeier NE, Mason HL. Student pharmacists' perceptions of testing and study strategies. Am J Pharm Educ. 2011;75(2):35-35.

11. Brown D. An evidence-based analysis of learning practices: the need for pharmacy students to employ more effective study strategies. Curr. Pharm Teach Learn. 2017;9(2):163-170.

12. Suda KJ, Bell GC, Franks AS. Faculty and student perceptions of effective study strategies and materials. Am J Pharm Educ. 2011; 75(10):Article 201.

13. Kornell N, Bjork RA. The promise and perils of self-regulated study. Psychon Bull Rev. 2007;14(2):219-224.

14. Yan VX, Thai K-P, Bjork RA. Habits and beliefs that guide selfregulated learning: do they vary with mindset? J Applied Res Mem Cogn. 2014;3(3):140-152.

15. Yang BW, Razo J, Persky AM. Using testing as a learning tool. Am J Pharm Educ. 2019;83(9):Article 7324.

16. McAndrew M, Morrow CS, Atiyeh L, Pierre GC. Dental student study strategies: are self-testing and scheduling related to academic performance? J Dent Educ. 2016;80(5):542-552.

17. Geller J, Toftness AR, Armstrong PI, et al. Study strategies and beliefs about learning as a function of academic achievement and achievement goals. Memory. 2018;26(5):683-690.

18. Cates ME, Clark A, Woolley TW, Saunders A. Sleep quality among pharmacy students. Am J Pharm Educ. 2015;79(1):Article 9. 19. Zeek ML, Savoie MJ, Song M, et al. Sleep duration and academic performance among student pharmacists. Am J Pharm Educ. 2015;79(5):Article 63.

20. Hirsch JD, Nemlekar P, Phuong P, et al. Patterns of stress, coping and health-related quality of life in doctor of pharmacy students: a five year cohort study. Am J Pharm Educ. 2020;84(3): Article 7547.

21. Garber MC. Exercise as a stress coping mechanism in a pharmacy student population. Am J Pharm Educ. 2017;81(3):50.
22. Hagemeier NE, Carlson TS, Roberts CL, Thomas M. A longitudinal analysis of first professional year pharmacy student wellbeing. Am J Pharm Educ. 2020;84(7):Article 7735.

23. Babal JC, Abraham O, Webber S, Watterson T, Moua P, Chen J. Student pharmacist perspectives of factors that influence wellbeing during pharmacy school. Am J Pharm Educ. 2020;84(9):Article 7831. 24. Rivers ML, Dunlosky J, Persky AM. Measuring metacognitive knowledge, monitoring, and control in the pharmacy classroom and experiential settings. Am J Pharm Educ. 2020;84(5):Article 7730. 25. Piza F, Kesselheim JC, Perzhinsky J, et al. Awareness and usage of evidence-based learning strategies among health professions students and faculty. Med Teach. 2019;41(12):1411-1418.

26. Gooding HC, Mann K, Armstrong E. Twelve tips for applying the science of learning to health professions education. Med Teach. 2017;39(1):26-31.

27. Medina MS, Plaza CM, Stowe CD, et al. Center for the Advancement of Pharmacy Education 2013 educational outcomes. Am J Pharm Educ. 2013;77(8):Article 162.

28. Allen DD. Leading the way in pharmacy education: diversity, equity and inclusion, wellness and resilience: address of the 20182019 president to the opening general session at the 2019 annual meeting. Am J Pharm Educ. 2019;83(6):Article 7781.

29. Chun Tie Y, Birks M, Francis K. Grounded theory research: a design framework for novice researchers. SAGE Open Med. 2019;7: $2050312118822927-2050312118822927$.

30. Biwer F, MGAo Egbrink, Aalten P, de Bruin ABH. Fostering effective learning strategies in higher education - a mixed-methods study. J Applied Res Mem Cogn. 2020;9(2):186-203.

31. Stewart D, Panus P, Hagemeier N, Thigpen J, Brooks L. Pharmacy student self-testing as a predictor of examination performance. Am J Pharm Educ. 2014;78(2):Article 32. 32. Karpicke JD, Blunt JR. Retrieval practice produces more learning than elaborative studying with concept mapping. Science. 2011;331(6018):772-775.

33. Karpicke JD, Butler AC, RoedigerHL , III. Metacognitive strategies in student learning: do students practise retrieval when they study on their own? Memory. 2009;17(4):471-479.

34. McDaniel MA, Donnelly CM. Learning with analogy and elaborative interrogation. J Educ Psychol. 1996;88(3):508-519. 35. Chi MTH, De Leeuw N, Chiu M-H, Lavancher C. Eliciting selfexplanations improves understanding. Cogn Sci. 1994;18(3):439-477. 36. Hernick M. Test-enhanced learning in an immunology and infectious disease medicinal chemistry/pharmacology course. Am J Pharm Educ. 2015;79(7):Article 97.

37. Smith BL, Holliday WG, Austin HW. Students' comprehension of science textbooks using a question-based reading strategy. $J$ Res Sci Teach. 2010;47(4):363-379.

38. Symons CS, Johnson BT. The self-reference effect in memory: a meta-analysis. Psychol Bull. 1997;121(3):371-394.

39. Rovers SFE, Stalmeijer RE, van Merriënboer JJG, Savelberg HHCM, de Bruin $\mathrm{ABH}$. How and why do students use learning strategies? a mixed methods study on learning strategies and desirable difficulties with effective strategy users. Front Psychol. 2018;9:2501-2501.

40. Sabourin AA, Prater JC, Mason NA. Assessment of mental health in doctor of pharmacy students. Curr Pharm Teach Learn. 2019;11(3):243-250.

41. Geslani GP, Gaebelein CJ. Perceived stress, stressors, and mental distress among doctor of pharmacy students. Soc Behav Personal. 2013;41(9):1457-1468. 